\title{
How Do We Manage a Just Transition? A Comparative Review of National and Regional Just Transition Initiatives
}

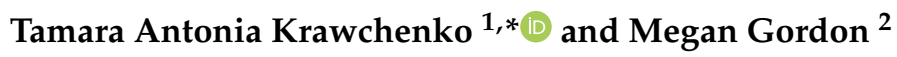 \\ 1 Public Administration/Faculty of Human and Social Development, University of Victoria, \\ Victoria, BC V8P 5C2, Canada \\ 2 Geography/Faculty of Environment, University of Northern British Columbia, \\ Prince George, BC V2N 4Z9, Canada; gordonm@unbc.ca \\ * Correspondence: TamaraKrawchenko@UVic.ca; Tel.: +1-250-721-6442
}

check for updates

Citation: Krawchenko, T.A.; Gordon, M. How Do We Manage a Just Transition? A Comparative Review of National and Regional Just Transition Initiatives. Sustainability 2021, 13, 6070. https://doi.org/10.3390/ su13116070

Academic Editor: Tomonobu Senjyu

Received: 13 May 2021

Accepted: 27 May 2021

Published: 28 May 2021

Publisher's Note: MDPI stays neutral with regard to jurisdictional claims in published maps and institutional affiliations.

Copyright: (c) 2021 by the authors. Licensee MDPI, Basel, Switzerland. This article is an open access article distributed under the terms and conditions of the Creative Commons Attribution (CC BY) license (https:// creativecommons.org/licenses/by/ $4.0 /)$.

\begin{abstract}
The concept of a 'just transition' encompasses political and policy imperatives to minimize the harmful impacts of industrial and economic transitions on workers, communities, and society more generally, and to maximize their potential benefits. This imperative has gained heightened importance as governments commit to reducing greenhouse gas emissions. A wide range of policies, strategies and initiatives have been adopted by national and regional governments to facilitate and help manage a just transition. It is a concept that is increasingly being put into practice. This scoping study identifies and compares strategies, policies, and practices that are presently being implemented in order to manage a just transition across 25 countries and 74 regions alongside European Unionlevel policies. This work develops a typology of policy instruments to manage just transitions and identifies implementation gaps and leading practices.
\end{abstract}

Keywords: just transition; energy transition; regional development; public policy; governance; OECD; European Union

\section{Introduction}

The concept of a 'just transition' encompasses a political imperative, a policy goal, and a set of practices meant to minimize the harmful impacts of industrial and economic transitions on workers, communities, and society at large. The term 'just transition' was first championed in the 1970s by the North American labor movement to describe a range of measures to secure workers' rights and livelihoods in the wake of government-led environmental legislation and regulations that could have labor impacts [1]. The idea of a 'just transition' became globally prominent in the context of international climate negotiations and through the advocacy of global union organizations [2-4]. This is evident in the sharp increase in the topic as a central theme in academic and think tank work, much of which has grappled with the dual responsibilities of reducing GHG emissions and addressing social justice issues in impacted regions [5]. Within a just transitions approach, justice can be conceived in distributional, procedural, and recognitional terms: distributional justice is concerned with how different groups benefit or experience impacts from the changes required; recognitional justice identifies interest groups and rights holders who may be implicated; and procedural justice is concerned with elements of governance-who is included and how [6-8].

The just transitions literature spans 'jobs-focused', 'environment-focused', and 'societyfocused' interpretations [3,6,8-12]. Each approach has implications for where and to whom governments focus their policy support and investments. The 'jobs-focused' interpretation advocates primarily for workers and communities impacted by environmental and climate policies. This interpretation has its roots in the original principles of labor leaders who coined the term. Advocates for a jobs-focused just transition are often social-democratic unions in regions that rely on carbon-intensive industries and resource extraction [9]. This 
interpretation is closely aligned with a 'differentiated responsibility' approach that assumes states and capital have a responsibility toward workers impacted by environmental regulations [3]. The 'environment-focused' interpretation of just transition evaluates transitions based on the primary objective of enabling the shift to a zero-carbon economy. Its lens is socio-technical-examining the production and consumption patterns of a sector $[8,10]$. 'Society-focused' interpretations adopt the broadest approach to just transition with the widest application of solutions. This approach views just transition measures as a means to uplift and support workers, communities, and society, and encompasses a broad range of interests and advocates for system transformation [6]. It advocates for universal equity and justice through addressing inequities on national and sub-national scales (e.g., marginalized communities facing disproportionate harms of resource development) and on a global scale (e.g., energy poverty in developing countries) $[5,13,14]$. Each of these have implications for the design of policy responses by governments.

This scoping study contributes to the just transitions literature by focusing on policy implementation for just transitions. It synthesizes national and regional initiatives, strategies, policies, and practices that are being presently implemented to manage a just transition across 25 countries (advanced OECD economies) and 74 regions plus European Union level policies. It develops a typology of national and regional policy practices and offers comparative policy learning.

\section{Methods: Comparative Policy Scoping Review}

This study has been conducted as a scoping review: "a form of knowledge synthesis that addresses an exploratory research question aimed at mapping key concepts, types of evidence, and gaps in research related to a defined area or field by systematically searching, selecting and synthesizing existing knowledge" [15] (p. 663). The content of national and regional just transition policies and practices have been collected and analyzed alongside a review of academic (peer-reviewed) and documents from other relevant public and non-profit organizations (e.g., International Labor Organization, Just Transition Center, Green New Deal). The inclusion criteria for this study were broad: any policies, strategies, and interventions directed to managing industrial transitions that address just transitions goals: both those that explicitly employ the term 'just transition' and those that do not.

The cases of interest were selected from among member countries of the Organization for Economic Cooperation and Development (OECD)—so-called 'advanced economies'. This study identified 130 sub-regional territories (TL3) across OECD countries where there has been a high share of employment in industry (more than a quarter out of total employment), which has subsequently declined in the past decade (timeframe 1999-2019). The data for this analysis was accessed from the OECD regional database (https: / / stats. oecd.org, accessed on 1 September 2021). Employment in industry (under ISIC Rev 4, B-5) includes the following: (A) mining and quarrying (B), manufacturing (C), electricity, gas and conditioning supply (D), water supply, sewerage, waste management and remediation activities, construction (F). Sub-regions were sorted according to the following four types (see Figures 1-3 below):

- Sub-regions that have undergone transition (transitioned regions): These 130 sub-regional territories show a declining trend going from a high share of employment to a lower share over the past two decades. These are TL3 regions where the share of employment in industry was greater than 25\% in industries including energy from 2000-2009 and less than 25\% from 2010-2019.

- Sub-regions that may face transition in the future (high industry regions): These sub-regions show a high share of employment in industry, greater than 25\% from 2000-2019.

- Sub-regions that are increasing in industrial employment (growing industry regions): These sub-regions demonstrate a higher share of employment in recent years: the share of employment in industry is greater than 25\% from 2010 onward. 
- Lower industry employment sub-regions (low industry regions): Sub-regions for which there is less than $25 \%$ share of employment in industry including energy. These are in effect "the rest" [16].

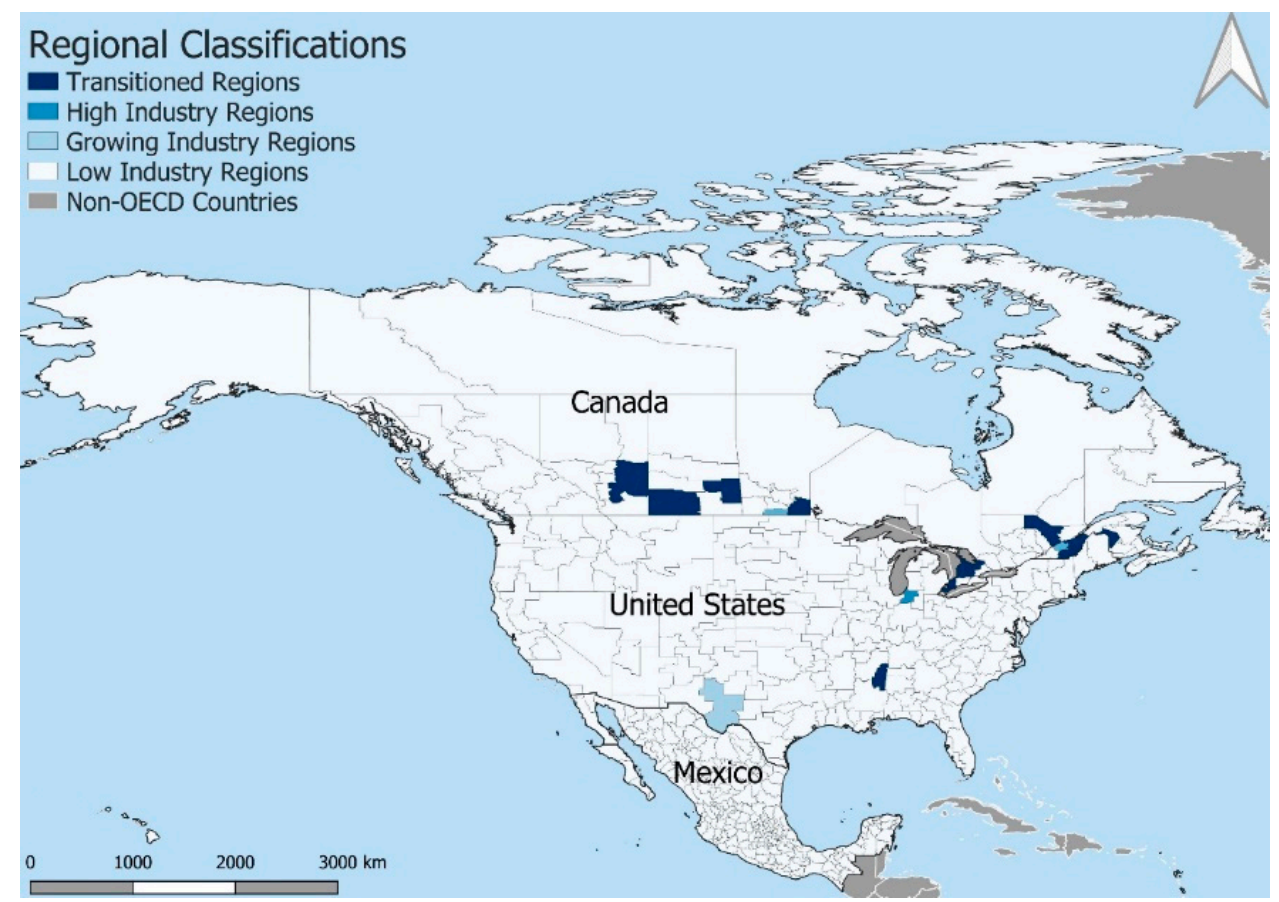

Figure 1. Case selection typology, North America. Source: Own elaboration.

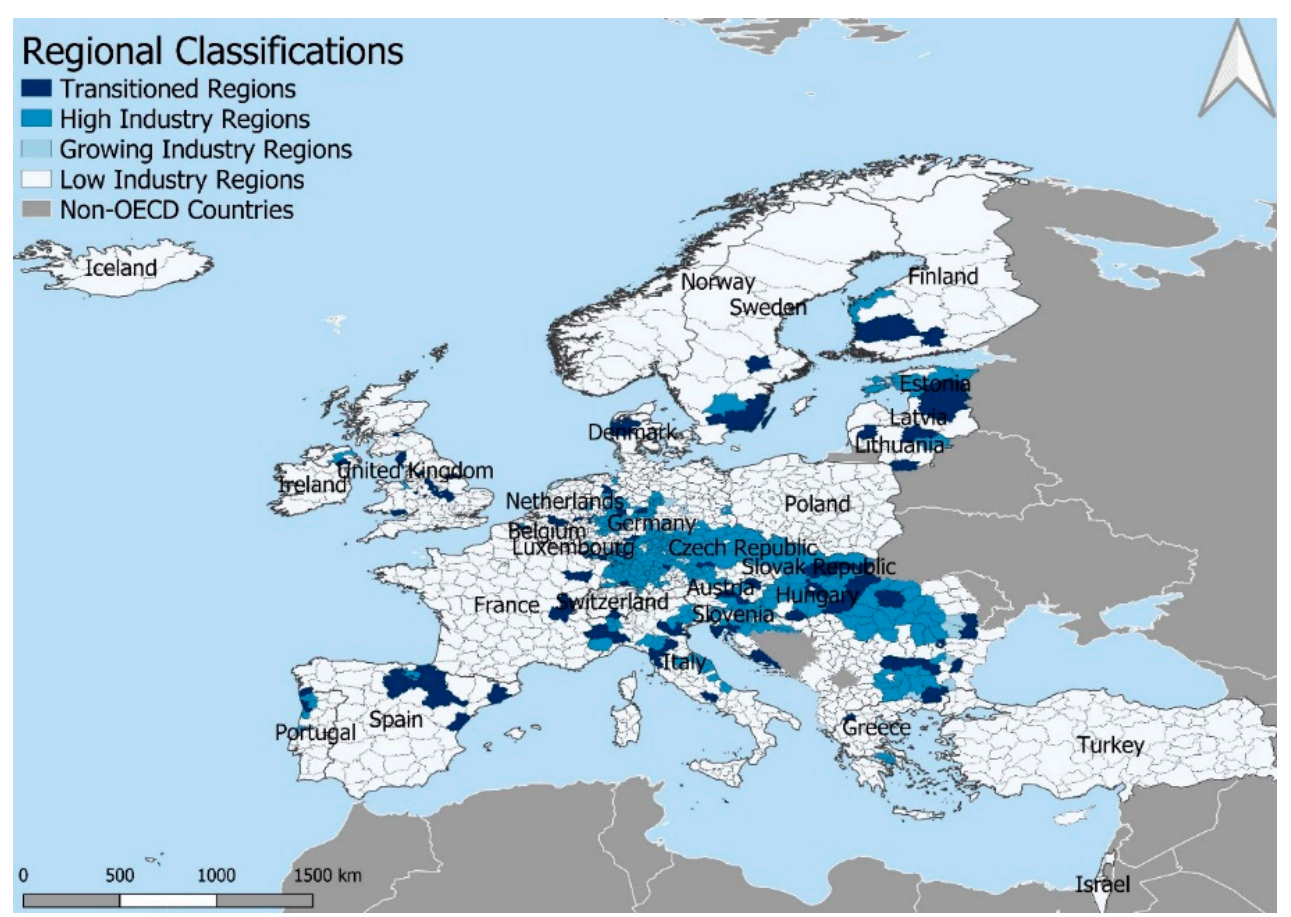

Figure 2. Case selection typology, Europe. Source: Own elaboration. 


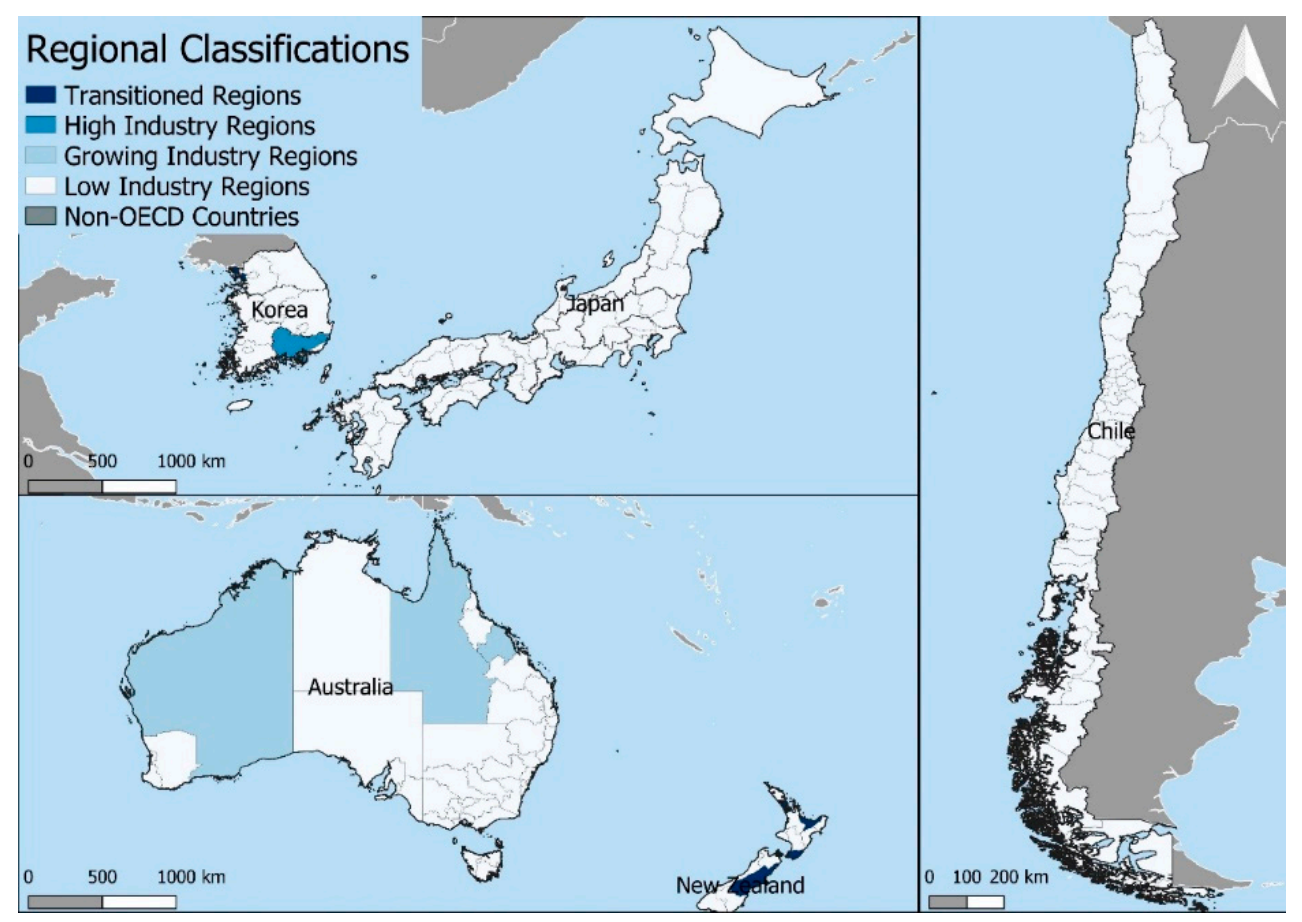

Figure 3. Case selection typology, Korea, Japan, Chile, Australia. Source: Own elaboration.

The first type-sub-regions that have undergone transition-formed the basis of case selection for the regional and national policy scan, resulting in a final selection of 74 regions across 25 counties.

Academic and policy literature, including government websites, were searched through a number of key search terms related to just transitions in order to develop a comprehensive understanding of the range of policies that are being used to manage industrial transitions (or not, as the case may be). The searches focused on policies, strategies, and interventions within the past five years (2015-2020). Multiple searches were conducted for the purposes of exhaustive coverage (facilitated by Google Translate for non-English and non-French documentation and studies). Search terms included a mix of policy instruments types (e.g., policy, strategy, commitment, program, initiative, mechanism, fund) alongside sectoral or thematic descriptors (e.g., industry, workforce, climate adaptation and mitigation, energy, energy transition, fair transition, transition, employment, community, coal). Literature was coded by key terms and core findings have been synthesized using Mendeley reference management software (using thematic tagging) and in Excel tables in order to identify the main thematic areas of policy interventions and strategies. The policy intentions (i.e., type of supports, how they were directed) were summarized, recoded, and thematically bundled, forming the basis of the comparative typology and summary tables. Wherever possible, comparative analysis was verified against existing resources [17]. There are a number of limitations of this study. This research relied on web searches of publicly available documentation, largely from government websites. It is possible that some information was not up to date and that, despite our best efforts at conducting comprehensive searches, important polices, initiatives, or strategies were missed.

\section{Results: National and Regional Just Transitions Initiatives}

This section provides an overview of national and regional just transition initiatives. Seven thematic policy areas of intervention were identified in this analysis:

1. Governance mechanisms: Measures to manage, coordinate, plan, and dedicate specific resources toward transition;

2. Climate and sustainability planning: Ensuring preparedness for the effects of climate change and realizing new opportunities in a green economy; 
3. Workforce development: Supporting employed and displaced workers with the skills, training, and information required to find and keep jobs;

4. Economic development: Creating new economic opportunities to replace traditional industries or update existing ones;

5. Regional and rural development: Ensuring all regions have the assets and capabilities to be successful and supporting places negatively impacted by industrial transitions;

6. Innovation and research: Ensuring readiness for an evolving global economy and advancing technology to ensure industries and regions are modern, efficient, and functional; and,

7. Social Supports: Ensuring access to basic financial and social supports during periods of economic change.

The remainder of this section describes the prevalence of national and regional initiatives across these seven thematic areas.

\subsection{National Initiatives}

The national cases span federal, quasi-federal, and unitary states and one supranational body in the case of the European Union (EU). Table 1 provides an overview of the national interventions by thematic area. A broad range of policy instruments can address aspects of a just transition; however, only those interventions that are specifically targeted to industries or regions/communities facing industrial transitions have been highlighted in blue.

A major delineation in approaches is the overarching policies and strategies that seek to propel socio-technical transitions toward new low carbon activities versus those that are directed to specified sectors or industries (in regions). Among the countries of study, only three have clearly defined just transitions mechanisms that are directed to specific sectors. These are:

- Canada's Task Force on Just Transition for Canadian Coal Power Workers and Communities, which developed recommendations on how to manage the transition [18]. This has subsequently resulted in federal funding for transition centers in impacted communities [19];

- Spain's Just Transition Agreements with territories experiencing coal mine, coal power plant, and nuclear power plant closures [20];

- New Zealand's Just Transition Unit housed in the Ministry of Business Innovation and Employment, which conducts research and provides advice to government on the challenges and opportunities created by the transition to a low-carbon economy [21].

These initiatives work in different ways. Canada's Just Transition Task Force has entailed a targeted response to the coal sector. An external group of experts was convened to understand the problem of coal phase outs in specific communities and 10 recommendations were subsequently made to the government on how they could act to support this process. These recommendations focus on multi-level government coordination with an emphasis on income and labor market supports and community investments (e.g., local infrastructure development). In 2019, the Government of Canada funded the fourth recommendation of the Task Force: to fund the establishment and operation of locallydriven transition centers in affected communities [18]. Canada has also agreed to fund the eighth recommendation to identify, prioritize, and fund local infrastructure projects in affected communities. The purpose of these units is to create a single hub for community members to access a wide range of services such as re-employment support, training, and social support services. The Government of Canada is discussing the creation of a new "Just Transition Act," which would update the Canadian Environmental Protection Act (CEPA) [22]. It is not yet clear what aspects of the environment the Act would address.

Spain's approach to managing just transitions is far more encompassing. Through its Just Transition Agreements, Spain has entered into pacts with social partners. For example, the transition deal between the government, trade unions, and the National Federation of Coal Mining Businesses (Carbunion) covers Spain's privately-owned pits until 2027 (other agreements will cover public sector mining operations and other industries such 
as electricity unions) [23]. EU regional development funds are a key part of Spain's just transitions efforts [24]. National and EU funding will support: (i) investments in business and clean energy initiatives (2019-2023); (ii) early retirement for miners over 48 and; (iii) retraining for green jobs; and, environmental restoration of the affected areas. This last point is worth noting-environmental restoration and land management are often absent from transition plans. For example, Canada's Just Transition Task Force made no recommendations to the government regarding environmental remediation and land management. Land is a critical asset in affected communities and, except for remediation and effective land management, these industrial closures could become a major liability for the community.

In contrast to Spain and Canada's just transition initiatives, New Zealand's Just Transition Unit offers a center of governmental expertise on how to manage just transitions and broker partnerships in affected regions. New Zealand has committed to a low carbon economy: the Climate Change Response (Zero Carbon) Amendment Act 2019 is now law and in 2018, it was announced that no further offshore oil and gas exploration permits would be issued. This transition impacts certain regions more than others. The Taranaki region-where the energy sector represents $28 \%$ of the regional economic output-has been a major focus of the unit's partnership efforts and governmental and local and regional partners have co-developed the Taranaki 2050 Roadmap, which sets out a strategy for economic diversification [25]. The work of New Zealand's Just Transitions Unit is notably proactive, seeking to identify regions that are (or will be) negatively impacted by ongoing efforts to decarbonize the economy and to co-develop new economic strategies. The just transitions literature as well as expert recommendations (such as by Canada's Task Force) all note the importance of early interventions. New Zealand's approach aims to do just that.

Among the vast majority of the countries studied, national level just transition plans are absent: this is about to change. In January 2020, the European Commission unveiled a Just Transition Mechanism that aims to mobilize EUR 150 billion (100 billion direct EC contribution, remaining matching funds) through three main mechanisms:

- A new Just Transition Fund that provides funding that should be matched by member states through the European Regional Development Fund (ERDF) and the European Social Fund Plus (ESF+).

- $\quad$ An InvestEU scheme that will provide financing according to just transition objectives in targeted territories. These funds will be used to support a wide range of projects including those for energy and transport infrastructure including gas infrastructure and district heating, but also decarbonization projects, economic diversification, and social infrastructure.

- A new loan facility leveraged by the European Investment Bank (EIB) that will primarily entail grants to public sector entities with resources to implement measures to facilitate the transition to climate neutrality [26].

EU countries will produce Territorial Just Transition Plans to 2030 that will describe the nature of the social, economic and environmental challenges stemming from fossil fuelrelated phase-outs and/or GHG decarbonizing initiatives. These will outline the transition process to 2030 including development, reskilling, and environmental rehabilitation [27]. The plans will detail timelines, operations, and governance mechanisms to meet prescribed targets. Thus, government planning in Europe is poised for change.

Overarching national transition strategies such as those being promoted by the EC's Just Transition Mechanism may bring coherence to what are at present a patchwork of initiatives related to the thematic policy areas relevant to industrial transition. Fourteen out of the 27 countries examined have binding net zero GHG commitments, with Finland's 2035 commitment being the earliest. However, only in eight cases do these commitments specifically address industrial or economic transformations. Coal phase out legislation, strategies, and commitments have been made in Austria, Canada, Denmark, Finland, France Germany, Greece, Italy, Latvia, Lithuania, New Zealand, Portugal, Slovakia, Sweden, and the UK. The Powering Past Coal Alliance-a group of 104 countries, cities, regions, and 
organizations aiming to accelerate the fossil-fuel phase out of coal-fired power stationshave been instrumental in building momentum on this. Despite these commitments, some would argue that the transition has not been actively planned and managed [28]. Almost all countries are investing in innovation and green energy, but these are not necessarily linked to economic development plans and regional development initiatives, nor do they address elements of justice (e.g., excluding important stakeholders and rights holders from decision making). Some countries have an energy transition fund (e.g., Belgium), but this is not linked to broader multi-level governance mechanisms.

Social insurance programs are another critical transition policy instrument which serve to support individuals who have lost their jobs as they transition to new employment, as does labor market support (e.g., skills upgrading, retraining, employment placement supports). These resources can be mobilized for targeted interventions; this is most commonly done at the regional or local level, depending on how these services are organized (i.e., they may not be absent, but delivered at a different scale). As a response to the COVID-19 pandemic, states have adopted a wide range of temporary income support for individuals who have lost their jobs. However, only the United States offers temporary income support for displaced workers in a specific industry - the U.S. Department of Labor offers POWER Dislocated Worker Grants and Resources for Coal Miners in three states (Ohio, Kentucky, and West Virginia) [29]. The United States also has a separate national pension plan for miners.

In the 14 countries that have national spatial planning frameworks, mechanisms to address the transitioning uses and remediation of land in high industry regions are absent. The European Commission's Just Transition Mechanism (JTM) is shifting the status quo as spatial plans will need to be submitted to the EC for approval for JTM funding. For example, Greece, which has vast lignite dependent regions, will need to present analytical spatial plans detailing spatial transitions in accordance with the National Energy and Climate Plan [30]. These plans will then be incorporated into the EU's National Strategic Reference Framework.

The just transitions policy landscape is quickly changing due to new climate commitments and economic stimulus measures as a response to COVID-19. For example, Korea's Green New Deal regulates and ends financing for coal plants, imposes phased carbon taxes, and increases "energy welfare" [31,32], and Germany's federal Structural Development Act provides support to lignite regions. While the policy response in some countries has been to embrace a decarbonization agenda and address the social aspects of such a shift, in others, carbon intensive industries are being championed as key to recovery efforts. For example, the Morrison government in Australia is promoting a "gas-led recovery" and the renewable energy target will not be extended beyond 2020 [33].

\subsection{Regional Initiatives}

Regional just transitions initiatives are described here as all those policies and interventions directed to managing industrial transitions at the subnational (regional) level that address just transitions goals. The jurisdictional responsibilities of regions differ across the countries examined, spanning federal, quasi-federal, and unitary systems. In countries such as Canada, regional governments (i.e., provincial and territorial government) are a constitutionally independent order of government and have important policy responsibilities including jurisdiction over health care, education, natural resources, and local government. Many regions (particularly in unitary states) are policy takers, with their capacities and scope for action disproportionately shaped by national governments. As such, national strategies, policies, and interventions shape regional agency and functions.

Industrial transitions are inherently place-based and, as such, regional policies are an important instrument to manage these transitions. This component of the research has examined the presence of industrial transition policies in 74 regions identified by their having sub regions where there has been a significant industrial shift in the past two decades. In the case of the region of Leverkusen Kreisfreie Stadt of Cologne, Germany, 
the share of employment was as high as 36\% (in 2000). The greatest proportional declines in industrial employment over the 2000-2019 regions were in New Zealand's Auckland and Wellington regions, Bay of Plenty region, and the West Lothian, Stoke-on-Trent, and Walsall regions of the UK. These places experienced rapid transformations as they shed industrial employment.

The regional scale is closer to workers, community members, and local governments than that of national governments and as such can work on the ground with local governments, residents, and businesses to support them [34]. This scan of regional strategies and policy instruments was conducted in order to determine whether initiatives could either: (i) be leveraged for the purpose of mitigating negative outcomes from industrial transition on workers and communities; or (ii) provide wide enough benefit to economic, social, or environmental outcomes in order to potentially cushion the negative outcomes of industrial transitions in regions. This included a review of plans and strategies that outline intentions and general approaches to a given subject (e.g., economy, environment). The presence of a strategy does not necessarily mean that there are funded actions associated with it. Strategies can be funded (i.e., clear budget allocations) or unfunded. Funded strategies that are accompanied by tangible, concrete actions and that include implementation plans are the most effective and often serve to coordinate actions across levels of government and between sectoral departments. It is also important to note that strategies are political documents and, as such, may be of a limited time perspective.

Out of the 74 regions examined, around a third (34\%) had regional level plans that address some aspect of a just transition. Among these, broad-based just transitions strategies were evident in around a third of the regions (32\%) while the remainder were focused on technology and innovation (25\%), circular economy (14\%), energy efficiency (14\%) climate change $(11 \%)$, skills $(7 \%)$, and coal phase-outs (7\%). In Germany, the coal phase out law has impacted many regions and there is a national compensation mechanism to facilitate this adjustment. There are regional energy strategies in several provinces; some of these have been developed in a participative manner and are described as best practices in the literature (e.g., Rhineland-Palatinate and North Rhine-Westphalia). Notable also is the creation of Just Transition Commissioners. Scotland's Just Transition Commission was established in 2019 to develop practical, realistic, affordable recommendations for action to meet Scotland's 2040 net zero emissions goal and its economic strategy. Ireland also has a Just Transitions Commissioner for the Midlands and there have been significant investments in communities facing industrial shifts (e.g., closure of peat harvesting operations). As noted in the previous section, this is a quickly changing field. Under the new 2021-2027 program in EU states, the Fair Transition Mechanism and Fund are being mobilized for regional development and other activities and, as such, a growing number of regions are orienting their regional operational programs around these objectives.

Ten regions were chosen to profile in greater detail how national and regional policies address industrial transitions in a given sub-region where clearly identifiable sectors were undergoing significant changes (e.g., automotive manufacturing, coal mining, etc.). These were: Ontario, Canada; Grand Est, France; Saarland, Germany; Western Macedonia, Greece; Peidmont, Italy; Incheon, Capital Region, Korea; Bay of Plenty, New Zealand; Basque Country, Spain; Kalmar, Småland with Islands, Sweden; and Wales, United Kingdom. Table 2 summarizes the distribution of regional instruments across these ten profiles. Some policy instruments do not neatly fit into one category; for example, while 'jobs and skills strategies' may be considered a workforce development instrument, employment centers, which are considered a social support instrument, may be included as part of jobs and skills strategies, or financed through these strategies. Similarly, there is significant overlap between industrial transition commitments, innovation investments and initiatives, and Industry 4.0 strategies. 
Table 1. National just transition initiatives and related policies by instrument type and country.

\section{Type of initiative}

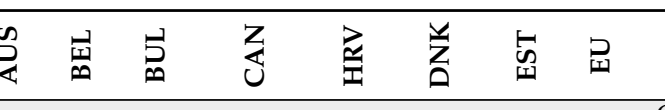

Consultations \& engagements GOVERNANCE

Multi-stakeholder collaborative tables

Coordination offices

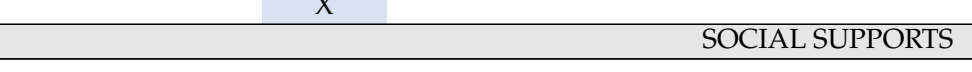

Temporary financial support for displaced workers

Employment services

$\mathrm{X}$ $X$
$X$ $X$

\begin{tabular}{|c|c|c|c|c|c|c|c|c|c|c|c|c|c|c|c|c|c|c|c|c|c|c|c|c|c|c|}
\hline $\begin{array}{l}\text { Temporary financial support for } \\
\text { displaced workers }\end{array}$ & $x$ & $\mathrm{X}$ & $x$ & $\mathrm{x}$ & $\mathrm{x}$ & $\mathrm{X}$ & $\mathrm{X}$ & & $\mathrm{X}$ & $\mathrm{X}$ & $X$ & $x$ & $X$ & $\mathrm{X}$ & $X$ & $x$ & $X$ & $X$ & $X$ & $X$ & $X$ & $x$ & $\mathrm{X}$ & $x$ & $x$ & $x$ \\
\hline Employment services & $\mathrm{X}$ & $\mathrm{X}$ & $\mathrm{X}$ & & $\mathrm{X}$ & $\mathrm{X}$ & $\mathrm{X}$ & & $\mathrm{X}$ & $\mathrm{X}$ & $\mathrm{X}$ & $\mathrm{X}$ & $\mathrm{X}$ & $\mathrm{X}$ & $\mathrm{X}$ & $\mathrm{X}$ & $\mathrm{X}$ & $\mathrm{X}$ & $\mathrm{X}$ & $\mathrm{X}$ & $\mathrm{X}$ & $X$ & $\mathrm{X}$ & $\mathrm{X}$ & & \\
\hline Social insurance/ unemployment support & $\mathrm{x}$ & $\mathrm{x}$ & $\mathrm{x}$ & $\mathrm{x}$ & $\mathrm{x}$ & $\mathrm{x}$ & $x$ & & $\mathrm{X}$ & $x$ & $x$ & $x$ & $x$ & $x$ & $\mathrm{X}$ & $\mathrm{X}$ & $\mathrm{X}$ & $x$ & $x$ & $\mathrm{X}$ & $\mathrm{X}$ & $\mathrm{X}$ & $\mathrm{X}$ & $\mathrm{x}$ & $\mathrm{x}$ & \\
\hline Pension supports & $\mathrm{X}$ & $\mathrm{X}$ & $\mathrm{X}$ & $\mathrm{X}$ & $\mathrm{X}$ & $\mathrm{X}$ & $\mathrm{X}$ & & $\mathrm{X}$ & $\mathrm{X}$ & $\mathrm{X}$ & $\mathrm{X}$ & $\mathrm{X}$ & $\mathrm{X}$ & $\mathrm{X}$ & $\mathrm{X}$ & $\mathrm{X}$ & $\mathrm{X}$ & $\mathrm{X}$ & $\mathrm{X}$ & $\mathrm{X}$ & $\mathrm{X}$ & $\mathrm{X}$ & $\mathrm{X}$ & $\mathrm{X}$ & $\mathrm{X}$ \\
\hline \multicolumn{27}{|c|}{ WORKFORCE DEVELOPMENT } \\
\hline Employment and skills strategies & $\mathrm{X}$ & $\mathrm{X}$ & $\mathrm{X}$ & $\mathrm{X}$ & $\mathrm{X}$ & $\mathrm{X}$ & $\mathrm{X}$ & & $\mathrm{X}$ & $\mathrm{X}$ & $\mathrm{X}$ & $\mathrm{X}$ & $\mathrm{X}$ & $\mathrm{X}$ & $\mathrm{X}$ & $\mathrm{X}$ & $\mathrm{X}$ & $\mathrm{X}$ & $\mathrm{X}$ & $\mathrm{X}$ & $\mathrm{X}$ & $\mathrm{X}$ & $\mathrm{X}$ & $\mathrm{X}$ & $\mathrm{X}$ & \\
\hline Training and education programs & $x$ & $x$ & $x$ & $\mathrm{X}$ & $\mathrm{X}$ & $\mathrm{X}$ & $\mathrm{X}$ & & $\bar{X}$ & $\mathrm{X}$ & $\mathrm{X}$ & $\mathrm{X}$ & $\mathrm{X}$ & $\mathrm{X}$ & $X$ & $X$ & $X$ & $\mathrm{X}$ & $\mathrm{X}$ & $\mathrm{X}$ & $\mathrm{X}$ & $X$ & $X$ & $\mathrm{X}$ & $\mathrm{X}$ & \\
\hline Job databases \& labor market info. & $\mathrm{x}$ & $x$ & $\mathrm{x}$ & $\mathrm{x}$ & $\mathrm{x}$ & $\mathrm{X}$ & $x$ & $x$ & $\mathrm{X}$ & $x$ & $x$ & $x$ & $x$ & $x$ & $x$ & $\mathrm{X}$ & $\mathrm{X}$ & $\mathrm{X}$ & $\mathrm{x}$ & $\mathrm{x}$ & $\mathrm{x}$ & $\mathrm{x}$ & $\mathrm{x}$ & $\mathrm{x}$ & $x$ & $\mathrm{x}$ \\
\hline \multicolumn{27}{|c|}{ ECONOMIC DEVELOPMENT } \\
\hline Business and tax incentives & $\mathrm{X}$ & $\mathrm{X}$ & $\mathrm{X}$ & $\mathrm{X}$ & $X$ & $X$ & $\mathrm{X}$ & $X$ & $X$ & $\mathrm{X}$ & $X$ & $X$ & $X$ & $\mathrm{X}$ & $X$ & $X$ & $X$ & $X$ & $\mathrm{X}$ & $X$ & $X$ & $X$ & $X$ & $\mathrm{X}$ & $\mathrm{X}$ & \\
\hline Sector-specific Investments & $\mathrm{x}$ & $\mathrm{x}$ & $\mathrm{x}$ & $x$ & $x$ & $x$ & $x$ & $x$ & $\mathrm{X}$ & $x$ & $x$ & $x$ & $x$ & $x$ & $\mathrm{X}$ & $\mathrm{X}$ & $x$ & $\mathrm{X}$ & $\mathrm{X}$ & $\mathrm{X}$ & $x$ & $\mathrm{x}$ & $\mathrm{X}$ & $\mathrm{x}$ & $\mathrm{x}$ & $\mathrm{x}$ \\
\hline $\begin{array}{c}\text { Small and medium-sized enterprises and } \\
\text { entrepreneurship support }\end{array}$ & $\mathrm{X}$ & $\mathrm{X}$ & $\mathrm{X}$ & $\mathrm{X}$ & $\mathrm{x}$ & $\mathrm{x}$ & $\mathrm{X}$ & $\mathrm{X}$ & $\mathrm{X}$ & $\mathrm{x}$ & $\mathrm{X}$ & $\mathrm{X}$ & $\mathrm{X}$ & $\mathrm{X}$ & $\mathrm{X}$ & $\mathrm{X}$ & $\mathrm{X}$ & $\mathrm{X}$ & $\mathrm{X}$ & $\mathrm{X}$ & $\mathrm{X}$ & $\mathrm{x}$ & $X$ & $\mathrm{X}$ & $\mathrm{X}$ & $\mathrm{X}$ \\
\hline \multicolumn{27}{|c|}{ REGIONAL DEVELOPMENT } \\
\hline Strategies \& plans & $\mathrm{X}$ & $\mathrm{X}$ & $\mathrm{X}$ & $\mathrm{X}$ & $\mathrm{X}$ & $\mathrm{X}$ & $\mathrm{X}$ & $\mathrm{X}$ & $\mathrm{X}$ & $\mathrm{X}$ & $\mathrm{X}$ & $\mathrm{X}$ & $\mathrm{X}$ & $\mathrm{X}$ & $\mathrm{X}$ & $\mathrm{X}$ & $\mathrm{X}$ & $\mathrm{X}$ & $\mathrm{X}$ & $\mathrm{X}$ & $\mathrm{X}$ & $\mathrm{X}$ & $\mathrm{X}$ & $\mathrm{X}$ & $\mathrm{X}$ & $\mathrm{X}$ \\
\hline Regional development program & $\mathrm{X}$ & $\mathrm{X}$ & $\mathrm{X}$ & $\mathrm{X}$ & $\mathrm{X}$ & $\mathrm{X}$ & $\mathrm{X}$ & $\mathrm{X}$ & $X$ & $\mathrm{X}$ & $\mathrm{X}$ & $\mathrm{X}$ & $\mathrm{X}$ & $\mathrm{X}$ & $\mathrm{X}$ & $\mathrm{X}$ & $\mathrm{X}$ & $X$ & $\mathrm{X}$ & $\mathrm{X}$ & $X$ & $\mathrm{X}$ & $\mathrm{X}$ & $\mathrm{X}$ & & $\mathrm{X}$ \\
\hline Rural development program & $\mathrm{X}$ & $X$ & $\mathrm{X}$ & & $\mathrm{X}$ & $\mathrm{X}$ & $\mathrm{X}$ & $\mathrm{X}$ & $\mathrm{X}$ & $X$ & $\mathrm{X}$ & $\mathrm{X}$ & $\mathrm{X}$ & $\mathrm{X}$ & $\mathrm{X}$ & $\mathrm{X}$ & $X$ & $\mathrm{X}$ & $\mathrm{X}$ & $X$ & $X$ & $X$ & $\mathrm{X}$ & $X$ & $\mathrm{X}$ & $\mathrm{X}$ \\
\hline Infrastructure investments & $\mathrm{X}$ & $\mathrm{X}$ & $\mathrm{X}$ & $\mathrm{X}$ & $\mathrm{X}$ & $\mathrm{X}$ & $\mathrm{X}$ & $\mathrm{X}$ & $\mathrm{X}$ & $X$ & $\mathrm{X}$ & $\mathrm{X}$ & $\mathrm{X}$ & $\mathrm{X}$ & $\mathrm{X}$ & $\mathrm{X}$ & $\mathrm{X}$ & $\mathrm{X}$ & $\mathrm{X}$ & $\mathrm{X}$ & $\mathrm{X}$ & $\mathrm{X}$ & $\mathrm{X}$ & $\mathrm{X}$ & $\mathrm{X}$ & $\mathrm{X}$ \\
\hline \multicolumn{27}{|c|}{ KNOWLEDGE ECONOMY, DIGITALIZATION, INDUSTRY 4.0} \\
\hline Innovation investments/ initiatives & $\mathrm{X}$ & $\mathrm{X}$ & $\mathrm{X}$ & $\mathrm{X}$ & $\mathrm{X}$ & $X$ & $\mathrm{X}$ & $\mathrm{X}$ & $\mathrm{X}$ & $\mathrm{X}$ & $\mathrm{X}$ & $X$ & $\mathrm{X}$ & $\mathrm{X}$ & $X$ & $\mathrm{X}$ & $\mathrm{X}$ & $\mathrm{X}$ & $\mathrm{X}$ & $\mathrm{X}$ & $\mathrm{X}$ & $X$ & $\mathrm{X}$ & $\mathrm{X}$ & $\mathrm{X}$ & $\mathrm{X}$ \\
\hline Industry 4.0 Strategy & $\mathrm{X}$ & & & & & & & & $\mathrm{X}$ & $\mathrm{X}$ & & $\mathrm{X}$ & & $\mathrm{X}$ & $\mathrm{X}$ & & & & & & & & $\mathrm{X}$ & $\mathrm{X}$ & & $\mathrm{X}$ \\
\hline $\begin{array}{l}\text { Funding for research and } \\
\text { higher education }\end{array}$ & $\mathrm{X}$ & $\mathrm{X}$ & $\mathrm{X}$ & & & $\mathrm{x}$ & $\mathrm{X}$ & $\mathrm{X}$ & $\mathrm{X}$ & $\mathrm{x}$ & $\mathrm{X}$ & & & $\mathrm{X}$ & $\mathrm{X}$ & & $x$ & & & $x$ & & & & $\mathrm{X}$ & $\mathrm{X}$ & $\mathrm{X}$ \\
\hline
\end{tabular}


Table 1. Cont

\begin{tabular}{|c|c|c|c|c|c|c|c|c|c|c|c|c|c|c|c|c|c|c|c|c|c|c|c|c|c|c|}
\hline Type of initiative & $\sum_{4}^{\infty}$ & 画 & S. & 玄 & 产 & 光 & 5 & ? & 竞 & $\underset{\mathbb{2}}{\mathbb{\Omega}}$ & 蛋 & Ư & 式 & 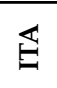 & 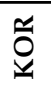 & 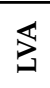 & 兒 & 攴 & $\stackrel{\mathrm{N}}{\mathrm{Z}}$ & 营 & ? & $y_{i}^{x}$ & 藏 & $\sum_{\infty}^{\infty}$ & 光 & 苑 \\
\hline \multicolumn{27}{|c|}{ CLIMATE SOLUTIONS } \\
\hline Binding net zero GHG commitment & 윰 & & & $\begin{array}{l}* \\
0_{0}^{2} \\
\stackrel{2}{1}\end{array}$ & & ஜั & & 오 & $\stackrel{\mathscr{N}}{\stackrel{N}{N}}$ & 芩 & 芩 & & ஜे & & 오 & & & & 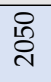 & ஜั & & 芩 & ڤั & 号 & ஜ̊̀ & \\
\hline Climate change \& energy strategies & $\mathrm{X}$ & $\mathrm{X}$ & $\mathrm{X}$ & $\mathrm{X}$ & $\mathrm{X}$ & $\mathrm{X}$ & $\mathrm{X}$ & & $\mathrm{X}$ & $\mathrm{X}$ & $\mathrm{X}$ & $\mathrm{X}$ & $\mathrm{X}$ & $\mathrm{X}$ & $X$ & $\mathrm{X}$ & $\mathrm{X}$ & $\mathrm{X}$ & $\mathrm{X}$ & $X$ & $\mathrm{X}$ & $\mathrm{X}$ & $\mathrm{X}$ & $\mathrm{X}$ & $\mathrm{X}$ & \\
\hline Adaptation programs & $\mathrm{X}$ & $\mathrm{X}$ & $\mathrm{X}$ & $\mathrm{X}$ & $\mathrm{X}$ & $\mathrm{X}$ & $\mathrm{X}$ & $X$ & $\mathrm{X}$ & $\mathrm{X}$ & $\mathrm{X}$ & $\mathrm{X}$ & $\mathrm{X}$ & $\mathrm{X}$ & $\mathrm{X}$ & $\mathrm{X}$ & $\mathrm{X}$ & $X$ & $\mathrm{X}$ & $\mathrm{X}$ & $\mathrm{X}$ & $\mathrm{X}$ & $\mathrm{X}$ & $\mathrm{X}$ & $\mathrm{X}$ & $\mathrm{X}$ \\
\hline Mitigation programs & $\mathrm{X}$ & $\mathrm{X}$ & $\mathrm{X}$ & $\mathrm{X}$ & $\mathrm{X}$ & $\mathrm{X}$ & $X$ & $X$ & $X$ & $X$ & $X$ & $X$ & $X$ & $X$ & $X$ & $X$ & $X$ & $X$ & $X$ & $X$ & $X$ & $X$ & $X$ & $X$ & $X$ & $\bar{X}$ \\
\hline $\begin{array}{l}\text { Investments in clean tech./ energy } \\
\text { transition fund }\end{array}$ & $x$ & $x$ & $x$ & $x$ & $x$ & $x$ & $x$ & $x$ & $x$ & $x$ & $x$ & $x$ & $x$ & $x$ & $x$ & $x$ & $x$ & $x$ & $x$ & $x$ & $x$ & $x$ & $x$ & $x$ & $x$ & $x$ \\
\hline
\end{tabular}

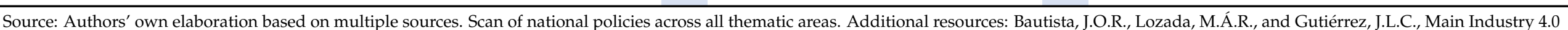

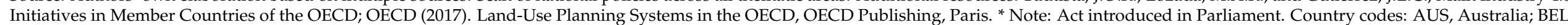

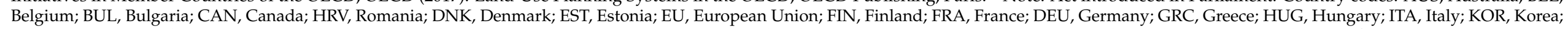
LVA, Latvia; LTU, Lithuania; MLT, Malta; NZL, New Zealand; PRT, Portugal; ROU, Romania; SVK, Slovakia; ESP, Spain; SWE, Sweden; UK, United Kingdom; USA, United States of America. 
Table 2. Regional just transitions initiatives and related policies.

\begin{tabular}{|c|c|c|c|c|c|c|c|c|c|c|c|c|c|c|c|c|c|c|c|c|c|}
\hline Type of Initiative & & & & & & & 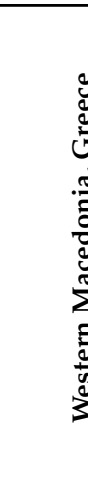 & & 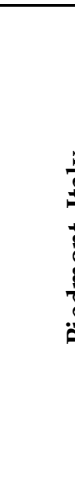 & & & & & & & & & & & 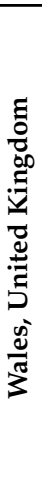 & \\
\hline $\begin{array}{l}\text { Territorial level of initiative } \\
\mathrm{R}=\text { Regional } \mathrm{N}=\text { National }\end{array}$ & $\mathrm{R}$ & $\mathrm{N}$ & $\mathrm{R}$ & $\mathrm{N}$ & $\mathrm{R}$ & $\mathrm{N}$ & $\mathrm{R}$ & $\mathrm{N}$ & $\mathrm{R}$ & $\mathrm{N}$ & $\mathrm{R}$ & $\mathrm{N}$ & $\mathrm{R}$ & $\mathrm{N}$ & $\mathrm{R}$ & $\mathrm{N}$ & $\mathrm{R}$ & $\mathrm{N}$ & $\mathrm{R}$ & & $\mathrm{N}$ \\
\hline \multicolumn{22}{|c|}{ GOVERNANCE } \\
\hline Expert panel consultations \& engagements & & $\mathrm{X}$ & & & & & & & & & & & & & & $\mathrm{X}$ & & & & & \\
\hline Multi-stakeholder collaborative tables & & $\mathrm{X}$ & & & $\mathrm{O}$ & & & & & & & & & $\mathrm{X}$ & & & & & & & \\
\hline Coordination offices & & $\mathrm{X}$ & & & $\mathrm{O}$ & & $\mathrm{O}$ & & & & & & & $\mathrm{X}$ & & $\mathrm{X}$ & & & & & \\
\hline \multicolumn{22}{|c|}{ SOCIAL SECURITY } \\
\hline Employment services & $\mathrm{O}$ & & & $\mathrm{X}$ & $\mathrm{O}$ & $\mathrm{X}$ & & $\mathrm{X}$ & & $\mathrm{X}$ & & $\mathrm{X}$ & & $\mathrm{X}$ & $\mathrm{O}$ & $\mathrm{X}$ & & $\mathrm{X}$ & $\mathrm{O}$ & & \\
\hline Social insurance/ unemployment support & & $X$ & & $\mathrm{X}$ & & $\mathrm{X}$ & & $\mathrm{X}$ & & $\mathrm{X}$ & & $\mathrm{X}$ & & $\mathrm{X}$ & & $\mathrm{X}$ & & $\mathrm{X}$ & & & $\mathrm{X}$ \\
\hline Community care programs & & & & & $\mathrm{O}$ & & & & $\mathrm{O}$ & & & & & & & & & & & & \\
\hline \multicolumn{22}{|c|}{ WORKFORCE DEVELOPMENT } \\
\hline Jobs and skills strategies & & $\mathrm{X}$ & $\mathrm{O}$ & $\mathrm{X}$ & & $\mathrm{X}$ & & $\mathrm{X}$ & & $\mathrm{X}$ & & $\mathrm{X}$ & & $\mathrm{X}$ & $\mathrm{O}$ & $\mathrm{X}$ & $\mathrm{O}$ & $\mathrm{X}$ & $\mathrm{O}$ & & $\mathrm{X}$ \\
\hline Training and employment programs & $\mathrm{O}$ & $\mathrm{X}$ & & $\mathrm{X}$ & $\mathrm{O}$ & $\mathrm{X}$ & & $\mathrm{X}$ & $\mathrm{O}$ & $\mathrm{X}$ & & $\mathrm{X}$ & & $\mathrm{X}$ & & $\mathrm{X}$ & & $\mathrm{X}$ & $\mathrm{O}$ & & $\mathrm{X}$ \\
\hline Job databases \& labor market info. & $\mathrm{O}$ & $x$ & & $x$ & & $\mathrm{X}$ & & $x$ & & $\mathrm{x}$ & & $x$ & & $x$ & & $x$ & & $x$ & & & $\mathrm{X}$ \\
\hline \multicolumn{22}{|c|}{ ECONOMIC DEVELOPMENT } \\
\hline Economic development strategies & & $\mathrm{X}$ & & & $\mathrm{O}$ & & $\mathrm{O}$ & & $\mathrm{O}$ & & $\mathrm{O}$ & & & & $\mathrm{O}$ & & & & $\mathrm{O}$ & & \\
\hline Industrial transition commitments/strategies & & & & $\mathrm{X}$ & & $\mathrm{X}$ & & $\mathrm{X}$ & & $\mathrm{X}$ & & $\mathrm{X}$ & & $\mathrm{X}$ & & $\mathrm{X}$ & & $\mathrm{X}$ & & & $\mathrm{X}$ \\
\hline Business and tax incentives & & $\mathrm{X}$ & & $\mathrm{X}$ & & $\mathrm{X}$ & & $\mathrm{X}$ & & $\mathrm{X}$ & $\mathrm{O}$ & $\mathrm{X}$ & & $\mathrm{X}$ & & $\mathrm{X}$ & & $\mathrm{X}$ & & & $\mathrm{X}$ \\
\hline Sector-specific Investments and programs & $\mathrm{O}$ & $X$ & $\mathrm{O}$ & $\mathrm{X}$ & $\mathrm{O}$ & $\mathrm{X}$ & $\mathrm{O}$ & $X$ & & $X$ & & $X$ & & $X$ & $\mathrm{O}$ & $X$ & & $X$ & $\mathrm{O}$ & & $\mathrm{X}$ \\
\hline $\begin{array}{c}\text { Small and medium-sized enterprises and } \\
\text { entrepreneurship support }\end{array}$ & & $\mathrm{X}$ & $\mathrm{O}$ & $x$ & $\mathrm{O}$ & $x$ & $\mathrm{O}$ & $\mathrm{x}$ & $\mathrm{O}$ & $x$ & & $x$ & & $x$ & $\mathrm{O}$ & $\mathrm{x}$ & $\mathrm{O}$ & $x$ & $\mathrm{O}$ & & $x$ \\
\hline
\end{tabular}


Table 2. Cont.

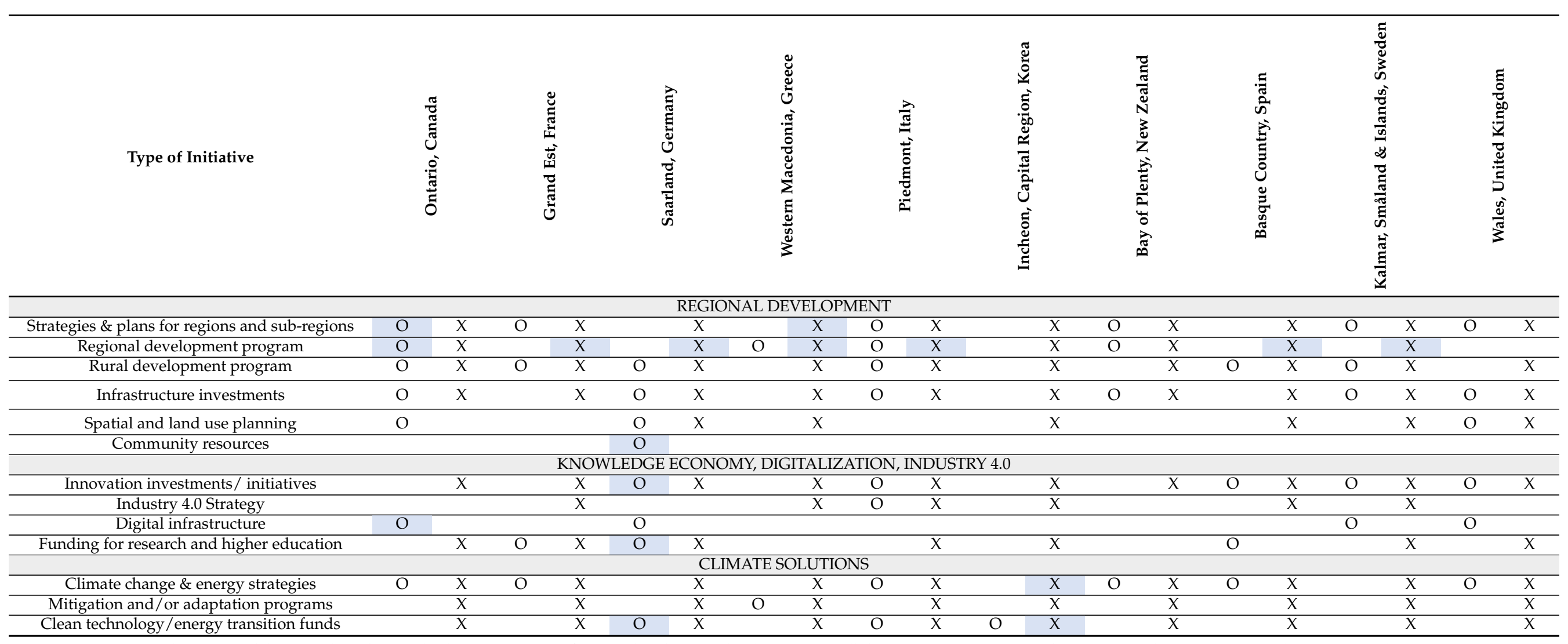

Source: Authors' own elaboration based on multiple sources. Scan of national and regional policies across all thematic areas. Note: $\mathrm{X}$ indicates national instrument; $\mathrm{O}$ indicates regional instrument. 


\section{Discussion: Leading Practices, Gaps, and Areas for Future Study}

This scoping review has examined the broad range of national and regional government just transitions initiatives in countries and regions that have experienced industrial transitions. This broad overview has uncovered a number of implementation gaps and identified several leading practices.

Managing a just transition is a multi-level government challenge. A multi-faceted issue such as just transition requires integration across policy areas. Across the countries and regions of study, infrastructure strategies, Industry 4.0 strategies, and workforce development plans commonly lack coordination mechanisms. Furthermore, economic development strategies commonly acknowledge the need for low carbon industries but they generally do not identify declining ones or the nature of their fixed infrastructure. The economic development strategies examined were generally poorly integrated with workforce development planning (i.e., skills and training). Economic development strategies and Industry 4.0 initiatives tend to display an urban bias, especially in terms of how technology and innovation are viewed. Innovation or Industry 4.0 measures tend to be focused on small and medium sized enterprises (SMEs) and not existing large industries. A gap in any of the above policy instrument areas means that key aspects of transition planning are absent, creating the risk of an inadequate or ineffective response to industrial transition. There are opportunities for regions and countries to link industrial transition strategies and clean growth opportunities, as demonstrated in the Korean New Deal: National Strategy for Great Transformation, which includes both a climate plan, a digitization plan, and foundational measures to strengthen the employment and social safety net, thus addressing several integrated policy issues under a single strategy.

Proactive initiatives are needed. Climate and economic strategies across the countries of study acknowledge that a shift toward less carbon intensive activities is needed and that this will impact the economy (and distinct regional economies). However, among the initiatives studied, very few have identified how those shifts can be proactively identified and addressed in order to facilitate their transition. This has been a common criticism of policies in support of coal transitions; they have often been adopted after the transition is already well underway, with workers and communities already impacted (e.g., the UK, Poland, and Greece). One exception is workforce development measures, which do tend to have a proactive outlook that anticipates the skills needed in the future (e.g., Future Skills Center, Canada; National Skills Strategy; Germany). However, these strategies are commonly implemented at the national level and are aspatial in their outlook. A leading practice for proactive measures is the Welsh Government's Future Generations Act and the establishment of the Future Generations Commissioner, whose role involves examining the long-term impacts of government decisions and prevent persistent problems such as poverty, health inequalities, and climate change. There is potential for an initiative such as this to hold decision makers to account and incentivize actions that emphasize long-term gains rather than short-term political wins that do not extend beyond electoral cycles. Among the practices reviewed, New Zealand's Just Transition Unit housed in the Ministry of Business Innovation and Employment does explicitly seek to provide research and advice to anticipate where future transitions will occur in order to coordinate actions and manage them [21]. As such, it is one example of proactive and anticipatory planning. However, it is not a center of government function and therefore the extent to which the Unit is able to coordinate actions across ministries is unclear.

Jobs-and environment-focused initiatives are the most common. Jobs-focused and environmentfocused strategies, polices, and initiatives were most prevalent among the countries of study. Well-developed workforce and skills strategies and wide ranging climate action plans were evident. However, society-focused framing was less common. The policy documents reviewed acknowledge that a society and economy wide transformation is needed, but the policy measures to support this were lacking. Among the regional profiles, it was found that social justice language was largely absent from industrial transition policies; that is, language rooted 
in whole economy thinking (e.g., addressing structural inequalities, social issues, matters of race, gender, socio-economic status, etc.).

Several policy levers are missing. This study examined how a wide range of initiatives address the aims of a just transition and how they are targeted to specific industries and regions experiencing these shifts. This overview has also revealed gaps, particularly with regard to spatial planning and land use, and the use of social security systems and direct funding to communities facing transitions.

- Land use is rarely recognized as an important policy lever for managing a just transition. Large industrial activities have major impacts on land and the environment, particularly where they involve mining, as in the case of coal. Land management is hence a key part of the transition process and becomes a great liability when remediation and rehabilitation are ignored. Moreover, poor and absent enforcement of environmental regulations for environmental remediation leaves communities with a colossal liability that impacts their future development potential. British Columbia's Dormant Sites Reclamation Program, which focuses on pandemic recovery, the cleanup orphan wells, and jobs creation, is a promising example [35].

- Social security systems are an underused policy mechanism to facilitate a just transition. Adaptable programs that permit carve-outs with flexible parameters can help provide timely support. This might entail expanding timeframes and amounts payable to those who have lost employment through employment insurance or establishing early pension systems for specific industries (e.g., coal pensions in the U.S.).

- Direct funding for community level economic development are not common among the regions studied. While it is well acknowledged that industrial transitions not only impact the workers employed in those sectors, but also in the broader community and local economy, community-oriented supports for a just transition were often absent. Some policies presume workers are mobile and will move to seek employment. While this may be true for some people, it is likely not true for all, as individuals often have deep connections and identities linked to their communities. An example of community economic development funding is the Rural Dividend Fund in British Columbia, Canada [36].

Finally, accountability mechanisms are needed for determinations of justice. Understanding how policy instruments and strategies address justice and equity is fundamental to public policy because it defines the parameters for success. When it comes to sustainability transitions, distributional justice is concerned with how different groups benefit or experience impacts from the changes required; recognitional justice identifies interest groups and rights holders who may be implicated; and procedural justice is concerned with elements of governance-who is included and how [6]. The establishment of Just Transitions Commissioners in Wales, Scotland, and Ireland is one accountability mechanism that governments could use to track, measure, and report on these elements of justice. The Commissioners act in a coordinating role within and between governments and report annually. A leading practice of a policy approach is the Hapū/Iwi Resource Management Plan in the Bay of Plenty, New Zealand. The plan established legislative requirements to ensure resource management issues important to local Indigenous peoples were taken into account. The inclusion of Indigenous peoples in decision making, particularly regarding resource development, is crucial in establishing recognitional, procedural, and distributional justices.

This national and regional policy review has explored interventions across seven thematic areas ranging from strategies and governance coalitions to sectoral funding programs to targeted supports for individuals and communities. This research raises a number of questions regarding the successful implementation of just transitions policies. To what extent are targeted national approaches warranted and what types of governance arrangements best facilitate this? As a multi-sectoral issue, where should coordination on just transitions 'sit' as a function within government? To what extent can overarching policies and programs in areas such as social support and workforce development facilitate just 
transitions-do they require adaptation to be more effective? What are the most effective interventions at the national level versus regional and local? Most critically, how do any of these policies address justice in procedural, recognitional, and distributional terms?

Author Contributions: Conceptualization, T.A.K. methodology, T.A.K.; validation, T.A.K.; formal analysis, T.A.K. and M.G.,; investigation, T.A.K. and M.G.; resources, T.A.K. and M.G.; data curation, T.A.K. and M.G.; writing—original draft preparation, T.A.K. and M.G.; writing-review and editing, T.A.K. and M.G.; visualization, T.A.K. and M.G.; supervision, T.A.K.; project administration, T.A.K.; funding acquisition, T.A.K. All authors have read and agreed to the published version of the manuscript.

Funding: This research was funded by the Social Sciences and Humanities Research Council of Canada, grant number \#872-2019-1004.

Acknowledgments: The authors are grateful for the support of the project team, which was comprised of Diana Gibson (Community Social Planning Council of Greater Victoria), Frederick Grouzet (Psychology, University of Victoria, UVic), Trevor Hancock (School of Public Health and Social Policy, UVic), Thomas Heyd (Philosophy, UVic), Katya Rhodes (School of Public Administration, UVic) and Karena Shaw (School of Environmental Studies, UVic). Many thanks to Darcy Harrison (UVic Geography) for creating the maps.

Conflicts of Interest: The authors declare no conflict of interest.

\section{References}

1. Smith, S. Just Transition a Report for the OECD; Extractives Hub: Dundee, UK, 2017.

2. Rosemberg, A. Building a Just Transition: The Linkages between Climate Change and Employment; International Labour Organization (ILO): Geneva, Switzerland, 2010.

3. Stevis, D.; Felli, R. Global labour unions and just transition to a green economy. Int. Environ. Agreem. Polit. Law Econ. 2014, 15, 29-43. [CrossRef]

4. COP 24 Just Transition Declaration-COP 24 Katowice. 2018. Available online: https://cop24.gov.pl/presidency/initiatives/justtransition-declaration/ (accessed on 18 August 2020).

5. Pai, S.; Harrison, K.; Zerriffi, H. A Systematic Review of the Key Elements of a Just Transition for Fossil Fuel Workers; Smart Prosperity Institute: Ottawa, ON, Canada, 2020.

6. Bennett, N.J.; Blythe, J.; Cisneros-Montemayor, A.M.; Singh, G.G.; Sumaila, U.R. Just Transformations to Sustainability. Sustainability 2019, 11, 3881. [CrossRef]

7. McCauley, D.; Heffron, R. Just transition: Integrating climate, energy and environmental justice. Energy Policy 2018, $119,1-7$. [CrossRef]

8. Newell, P.; Mulvaney, D. The political economy of the "just transition". Geogr. J. 2013, 179, 132-140. [CrossRef]

9. Evans, G.; Phelan, L. Transition to a post-carbon society: Linking environmental justice and just transition discourses. Energy Policy 2016, 99, 329-339. [CrossRef]

10. Meadowcroft, J. What about the politics? Sustainable development, transition management, and long term energy transitions. Policy Sci. 2009, 42, 323-340. [CrossRef]

11. Mertins-Kirkwood, H. Making Decarbonization Work for Workers Policies for a just Transition to a Zero-Carbon Economy in Canada; CCPA National Office: Ottawa, ON, Canada, 2018.

12. Goddard, G.; Farrelly, M.A. Just transition management: Balancing just outcomes with just processes in Australian renewable energy transitions. Appl. Energy 2018, 225, 110-123. [CrossRef]

13. Delina, L.L.; Sovacool, B.K. Of temporality and plurality: An epistemic and governance agenda for accelerating just transitions for energy access and sustainable development. Curr. Opin. Environ. Sustain. 2018, 34, 1-6. [CrossRef]

14. McCauley, D.; Ramasar, V.; Heffron, R.J.; Sovacool, B.K.; Mebratu, D.; Mundaca, L. Energy justice in the transition to low carbon energy systems: Exploring key themes in interdisciplinary research. Appl. Energy 2019, 233-234, 916-921. [CrossRef]

15. Colquhoun, H.L.; Levac, D.; O’Brien, K.K.; Straus, S.; Tricco, A.C.; Perrier, L.; Kastner, M.; Moher, D. Scoping reviews: Time for clarity in definition, methods, and reporting. J. Clin. Epidemiol. 2014, 67, 1291-1294. [CrossRef] [PubMed]

16. OECD. OECD Regional Database; OECD: Paris, France, 2020.

17. OECD. Land-Use Planning Systems in the OECD: Country Fact Sheets; OECD: Paris, France, 2017; ISBN 9264268561.

18. Government of Canada. Task Force: Just Transition for Canadian Coal Power Workers and Communities. Available online: https:/ / www.canada.ca/en/environment-climate-change/services/climate-change/task-force-just-transition.html (accessed on 17 December 2019).

19. Government of Canada. Budget 2019. Available online: https://www.budget.gc.ca/2019/home-accueil-en.html (accessed on 17 November 2020). 
20. Government of Spain. Acta Sobre los Puntos Básicos del Preacuerdo Para Una Transición Justa de la Minería Del Carbón y Desarrollo Sostenible de las Comarcas Mineras Para El Periodo 2019-2027. Available online: https://news.industriall-europe.eu/ content/documents/upload/2018/10/636754675904108696_ES-1165_001(003).pdf (accessed on 17 November 2020).

21. Government of New Zealand. Just Transition I Ministry of Business, Innovation \& Employment. Available online: https: //www.mbie.govt.nz/business-and-employment/economic-development/just-transition (accessed on 17 November 2020).

22. Pinkerton, C. First Environmental Action for Liberals Could Include "Just Transition Act", Strengthening CEPA-IPolitics. Available online: https://ipolitics.ca/2020/01/21/ first-environmental-action-for-liberals-could-include-just-transition-actstrengthening-cepa / (accessed on 17 November 2020).

23. Press, E. Gobierno, Eléctricas Y Sindicatos Rubrican un Acuerdo Para Impulsar Los Convenios de Transición Justa; Europa Press: Madrid, Spain, 2020.

24. La Comarca. La Comisión de Seguimiento Para la Transición Justa Hace un Balance Inicial Positivo. Available online: https: / / www.lacomarca.net/comision-seguimiento-transicion-justa-hace-balance-inicial-positivo/ (accessed on 17 November 2020).

25. Venture Taranaki. Taranaki 2050. Available online: https:/ /about.taranaki.info/taranaki2050 (accessed on 17 November 2020).

26. European Commission. Just Transition Funding Sources. Available online: https://ec.europa.eu/info/strategy/priorities-2019-2 024/european-green-deal/actions-being-taken-eu/just-transition-mechanism/just-transition-funding-sources_en (accessed on 27 October 2020).

27. European Commission. Just Transition Platform I European Commission. Available online: https://ec.europa.eu/info/strategy/ priorities-2019-2024/european-green-deal/actions-being-taken-eu/just-transition-mechanism/just-transition-platform_en (accessed on 17 November 2020).

28. Fothergill, S. Coal Transition in the United Kingdom; IDDRI: Paris, France, 2017.

29. U.S. Department of Labor. Power Dislocated Worker Grants-Resources for Coal Miners. Available online: https: / /www.dol.gov / agencies/owcp/dcmwc/powergrants (accessed on 13 November 2020).

30. Energy Press. Decarbonization Strategy's Spatial Planning Enters Crucial Stage. Available online: https://energypress.eu/tag/ national-energy-and-climate-plan/ (accessed on 9 December 2020).

31. Government of Korea. What Is Energy Welfare? Seoul Energy Corporation. Available online: https://www.i-se.co.kr/welfare? fbclid=IwAR1rNj_aSU9g1sCRuiO17Nu0rnTkC6FachHO7tpFgbZcPLYgCeHqaM9RKJo (accessed on 18 November 2020).

32. Energy Transition Korea. The Core of the Green New Deal Is Energy Conversion, Climate Crisis Response and Job Creation at the Same Time I Energy Conversion Forum. Available online: http://energytransitionkorea.org/post/29273 (accessed on 18 November 2020).

33. Prime Minister of Australia. Gas-fired Recovery / Prime Minister of Australia. Available online: https://www.pm.gov.au/media/ gas-fired-recovery (accessed on 19 November 2020).

34. Markey, S.; Halseth, G.; Manson, D. Investing in Place: Economic Renewal in Northern British Columbia; UBC Press: Vancouver, BC, Canada, 2012.

35. Government of Canada. Cleaning Up Dormant Oil and Gas Wells, Supporting 1200 Jobs in BC. Available online: https: / / www.canada. ca/en/natural-resources-canada/news/2020/09/cleaning-up-dormant-oil-and-gas-wells-supporting-1200-jobs-in-bc9.html (accessed on 16 March 2021).

36. Government of British Columbia. BC Rural Dividend-Province of British Columbia. Available online: https://www2.gov.bc.ca/ gov/content/employment-business / economic-development/support-organizations-community-partners/rural-economicdevelopment/rural-dividend (accessed on 17 December 2020). 